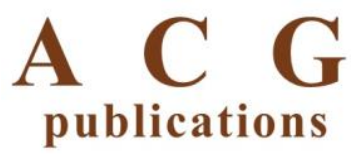

Rec. Nat. Prod. 12:5 (2018) 493-497

records of natural

products

\title{
A New ent-Pimarane-Type Diterpenoid Glycoside from Siegesbeckia pubescens
}

\author{
Fengqing $\mathrm{Xu}^{\oplus *}$, Huaping $\mathrm{Hu}^{\oplus}$, Ying $\mathrm{Li}^{\oplus}$, Yashuo Ren ${ }^{\oplus}$, Hongsu Zhao ${ }^{\oplus}$, Qi \\ Huang ${ }^{\oplus}$ and Jutao Wang ${ }^{\oplus *}$
}

School of Pharmacy, Anhui University of Chinese Medicine; Anhui Innovative Team from Colleges for

Scientific Research's Platform -The Innovative Team in Researching the Key Technologies concerning the Integration of Processing Chinese Medicine Decoction Pieces in Producing Area, Hefei 230012,

\author{
P. R. China
}

(Received November 22, 2017; Revised December 15, 2017; Accepted December 16, 2017)

\begin{abstract}
A new ent-pimarane-type diterpenoid glucoside, along with eight known same skeleton type were isolated from the ethanol extract of Siegesbeckia pubescens Makino by means of various chromatographic techniques (silica gel, RP-8, Sephadex LH-20, Pre-HPLC). Their structures were elucidated on the basis of spectroscopic analyses and the new one identified as ent-15-methylene-2 $\alpha, 16,19$-trihydroxy-pimar-8(14)-ene-19O- $\beta$-D-glucopyranoside.
\end{abstract}

Keywords: Siegesbeckia pubescens; ent-pimarane-type diterpenoid; pubeside F. C 2018 ACG Publications. All rights reserved.

\section{Introduction}

The genus Siegesbeckia is a small member of Compositae family and only comprises four species, which distributed in tropical, subtropical, and temperate parts of the world [1]. Three species are found in China and have used as "Xi-Xian" included in Chinese Pharmacopoeia for their antirheumatic, lubricate joints and detoxifying properties[2]. Bioactivity studies on extracts or pure components have exhibited multiple positive effects, including antithrombotic, anti-inflammatory, antiallergic, immunesuppressive and so on [3-6]. Siegesbecia pubescens Makino, an annual herb plant, is widely growing in the Midlands and the North of China. Previous investigation on S. pubescens, ent-kaurane and entpimarane diterpenoids were the main compositions of the plant and exhibited antithrombotic activity[5,7-8]. In the present study, we report the isolation and structure eluciation of a new entpimarane diterpenoid, together with eight known ones from the-BuOH part of the enthanol extract.

\footnotetext{
* Corresponding authors: E-mail: hfglnds@ sina.com (Fengqing Xu) and wjt591@163.com (Jutao. Wang), Phone: +8655168129167.
} 

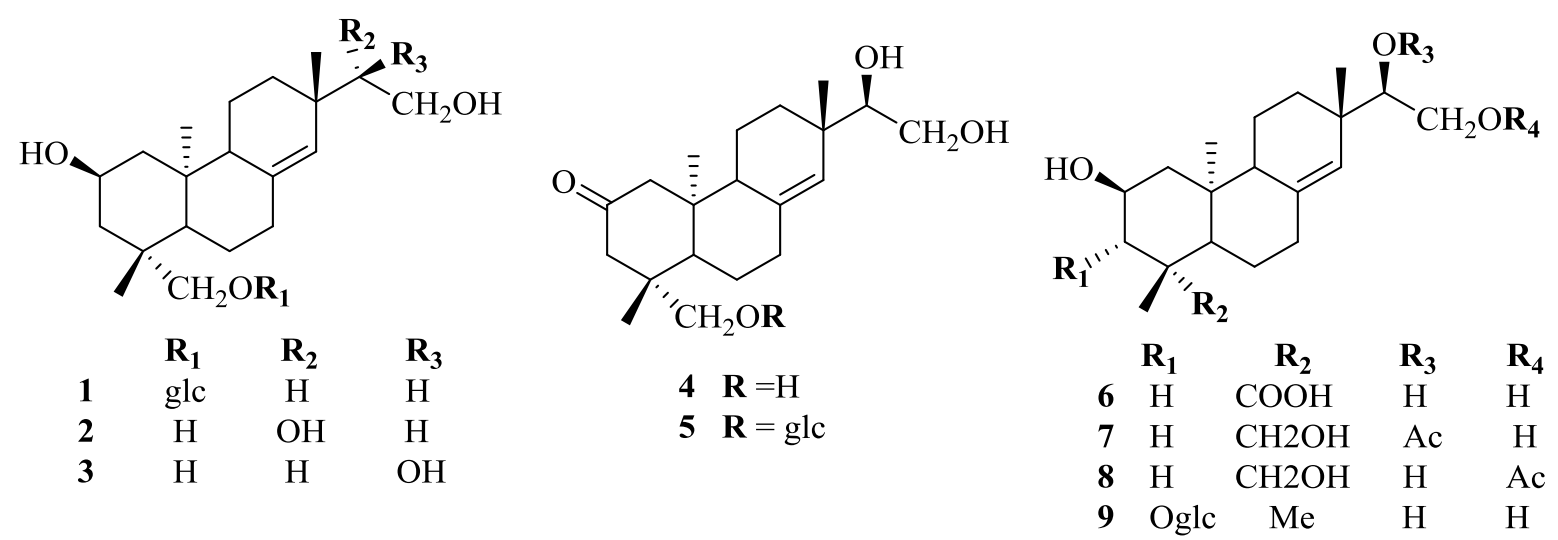

Figure 1. Chemical Structures of compounds 1-9

\section{Materials and Methods}

\subsection{Material}

The aerial of $S$. pubescens Makino was collected from Yuexi County, Anhui Province, China, in October 2009. It was identified by Dr. Qing-Shan Yang, Anhui University of Chinese Medicine. A voucher specimen (XF 201301) was deposited at the deposited at the Laboratory of Phytochemistry, Anhui University of Chinese Medicine.

Optical rotation was recorded on a Jasco P-1020 automatic digital polarimeter. UV spectrum was measured on a Shimadzu UV-2401PC spectrophotometer. IR spectrum was obtained on a Bruker Tensor 27 FT -IR spectrometer with KBr pellet. NMR spectra were recorded on Bruker DRX-400 instruments with TMS as the internal standard. The chemical shifts were given in $\delta$ (ppm) scale with reference to the solvent signal. ESI-MS and HR-ESI-MS spectra were acquired on API QSTAR Pulsar i mass spectrometer. Silica gel (200-300 mesh); and Sephadex LH-20 were used for column chromatography (CC). Preparative HPLC was performed on Waters Auto Purification 2545-2489 system equipped with a Shimadzu ODS-18, $9.4 \mathrm{~mm} \times 250 \mathrm{~mm}$ column. Fractions monitored by TLC, and spots were visualized by spraying with $10 \% \mathrm{H}_{2} \mathrm{SO}_{4}$ in $\mathrm{EtOH}$, followed by heating.

\subsection{Extraction and Isolation}

The air-dried and powdered aerial of $S$. pubescens Makino $(10.7 \mathrm{~kg})$ was diacolated with $95 \%$ ethanol $(100 \mathrm{~L})$ and $70 \%$ ethanol $(30 \mathrm{~L})$ at room temperature. The ethanol extract concentrated in vacuo to give a green crude extract, which was suspended in $\mathrm{H}_{2} \mathrm{O}$ and partitioned successively with petroleum ether (PE), EtOAc and $n$-BuOH. The $n$-BuOH part (264.2 g) was chromatographed on silica gel column $(2.0 \mathrm{~kg}, 9.0 \times 60 \mathrm{~cm})$ eluting with a $\mathrm{CH}_{2} \mathrm{Cl}_{2}-\mathrm{MeOH}$ gradient system $(95: 5,90: 10$, 85:15, 80:20, 70:30 each $20 \mathrm{~L}, \mathrm{v} / \mathrm{v}$ ) to afford fraction Fr.1 Fr.6. Each Fraction was decolorized using MCI gel CHP 20P $(0.8 \mathrm{~L}, 4.0 \times 80 \mathrm{~cm})$, eluted with $80 \% \mathrm{MeOH}-\mathrm{H}_{2} \mathrm{O}$, and then subjected to Sephadex LH-20 $(80 \mathrm{~g}, 2.0 \times 150 \mathrm{~cm})$ eluting with $\mathrm{MeOH}$ to yield sub-fractions. Fr.2-2 $(1.8 \mathrm{~g})$ was separated on silica gel column, eluted with $\mathrm{CH}_{2} \mathrm{Cl}_{2}-\mathrm{MeOH}(92: 8)$ to give $7(83 \mathrm{mg})$, the rest mix ingredient was purified by preparative $\mathrm{HPLC}$ using $35 \% \mathrm{MeOH}-\mathrm{H}_{2} \mathrm{O}$ detected at $215 \mathrm{~nm}$ to provide $7(25 \mathrm{mg})$ and $\mathbf{8}$ (54 mg). Fr. 4-2 (8.3 g) was chromatographed on silica gel column eluted with $\mathrm{CH}_{2} \mathrm{Cl}_{2}-\mathrm{MeOH}$ (90: 10) to yield 9 (1.26 g). Fr. 4-3 (0.83 g) was subjected to Rp-18 column eluted with $60 \% \mathrm{MeOH}-\mathrm{H}_{2} \mathrm{O}$, and positive Fr. 4-3-2 (30.6 mg ) was purified by preparative HPLC using $45 \% \mathrm{MeOH}-\mathrm{H}_{2} \mathrm{O}$ and provided $2(7.3 \mathrm{mg})$ and 3 (11.6 mg). Fr. 4-4 (1.31 g) was subjected to silica gel column eluted with $\mathrm{CH}_{2} \mathrm{Cl}_{2}-$ $\mathrm{MeOH}(90: 10)$ to provide $4(12.8 \mathrm{mg})$. Fr. $4-4(0.83 \mathrm{~g})$ was subjected to silica gel CC eluted with $\mathrm{CH}_{2} \mathrm{Cl}_{2}-\mathrm{MeOH}(85: 15)$ to obtain 5 (31.8 mg). Fr. 5.2 (1.48 g) was applied an RP-18 column and isocratic elution $\left(60 \% \mathrm{MeOH}-\mathrm{H}_{2} \mathrm{O}\right)$ to yield Fr. 5.2.2, which further purified by preparative HPLC $\left(40 \% \mathrm{MeOH}-\mathrm{H}_{2} \mathrm{O}\right)$ to afford $\mathbf{6}(8 \mathrm{mg})$. Compound $1(13 \mathrm{mg})$ was isolated from Fr.5.3 using repeated silica gel CC with $\mathrm{CH}_{2} \mathrm{Cl}_{2}-\mathrm{MeOH}(85: 15)$ and preparative $\mathrm{HPLC}$ with $45 \% \mathrm{MeOH}-\mathrm{H}_{2} \mathrm{O}$. 


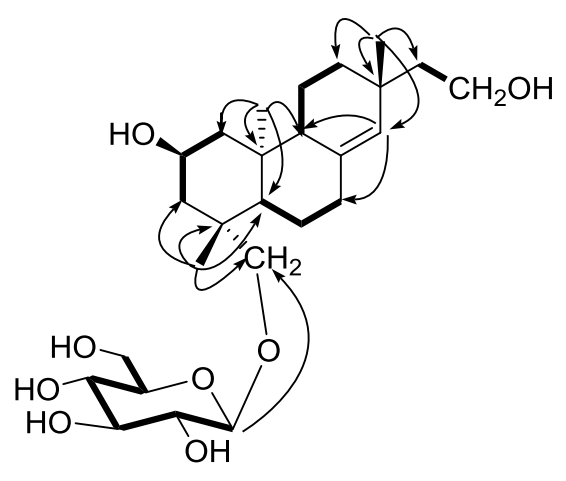

Figure 2. Key ${ }^{1} \mathrm{H}^{-1} \mathrm{H}$ COSY and $\mathrm{HMBC}$ correlations of compound $\mathbf{1}$

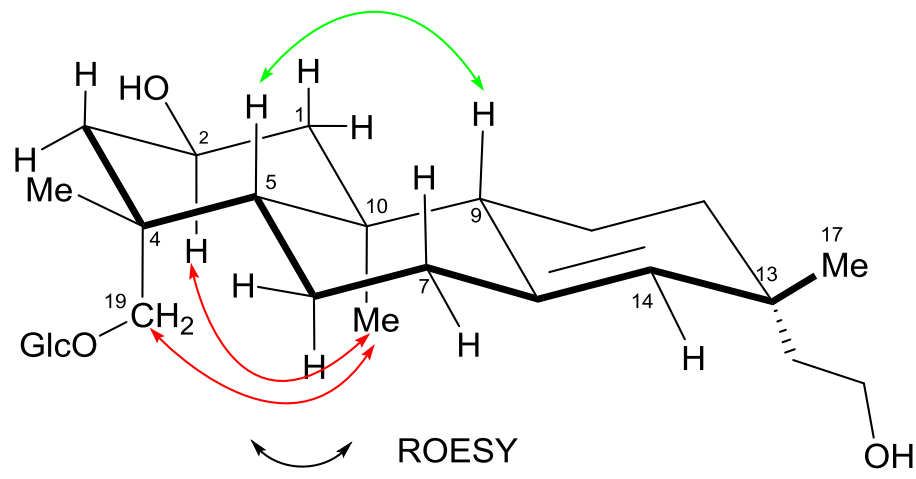

Figure 3. Key ROESY corrections of compound 1

\subsection{Spectroscopic Data}

Pubeside $F(\mathbf{1})$ : White amorphous power; $[\alpha]_{\mathrm{D}}^{20.0}=-32.20$ (c $\left.0.001, \mathrm{MeOH}\right) ; \mathrm{UV}(\mathrm{MeOH}): \lambda_{\max }(\log$ $\varepsilon)=204(3.75) \mathrm{nm} ; \mathrm{IR}(\mathrm{KBr}): v_{\max }=3416,2924,2850,1645,1597,1464,1375,1080 \mathrm{~cm}^{-1} ;{ }^{1} \mathrm{H}-\mathrm{NMR}$ and ${ }^{13} \mathrm{C}$-NMR (MeOD, 400/100 MHz) see Table 1; HR-ESI-MS calcd for $\mathrm{C}_{26} \mathrm{H}_{44} \mathrm{O}_{8} \mathrm{Na}[\mathrm{M}+\mathrm{Na}]^{+}$ 507.2934, found 507.2926.

\subsection{Acid Hydrolysis}

Compound $1(3 \mathrm{mg})$ were individually refluxed with $5 \% \mathrm{HCl}$ in $\mathrm{MeOH}(5 \mathrm{~mL})$ for 4 hours. The solution was diluted with $\mathrm{H}_{2} \mathrm{O}(5 \mathrm{~mL})$ and extracted with EtOAc $(10 \mathrm{~mL})$ for 3 times. The aqueous layer was neutralized with $\mathrm{NaHCO}_{3}$ and concentrated in vacumn to give a residue. The residue was purified by RP-18 column, eluted with $20 \% \mathrm{MeOH}-\mathrm{H}_{2} \mathrm{O}$. The sugar unit was identified as D-glucose on the basis of TLC and optical rotation $\left([\alpha]_{\mathrm{D}}{ }^{18.3}:+40.0(\mathrm{c} 0.05, \mathrm{MeOH})\right)[9,10]$.

\section{Results and Discussion}

\subsection{Structure Elucidation}

Compound 1 was obtained as a white amorphous power. Its molecular formula was determined to be $\mathrm{C}_{26} \mathrm{H}_{44} \mathrm{O}_{8}$ with five degrees of unsaturation on the basis of the HR-ESIMS (positive ion): $\mathrm{m} / \mathrm{z}$ 507.2926 $[\mathrm{M}+\mathrm{Na}]^{+}$(calcd. for $\mathrm{C}_{26} \mathrm{H}_{44} \mathrm{O}_{8} \mathrm{Na}$ ) and the ${ }^{13} \mathrm{C}$ NMR data (Table1). The IR spectrum showed the presence of hydroxyl $\left(3416 \mathrm{~cm}^{-1}\right)$ and double bond $\left(1645 \mathrm{~cm}^{-1}\right)$ functionalities. The ${ }^{1} \mathrm{H}$ NMR spectrum of 1 exhibited three methyl singlet signals at $\delta_{\mathrm{H}} 0.85,0.94,1.09$; three oxygenated- 
methylene groups $\left[\delta_{\mathrm{H}} 4.04,3.31(1 \mathrm{H}\right.$ each, $\mathrm{d}, 11.6 \mathrm{~Hz}), 3.61(2 \mathrm{H}, \mathrm{m})$ and $3.87(1 \mathrm{H}, \mathrm{dd}, 12.0,6.2 \mathrm{~Hz})$, $3.71(1 \mathrm{H}, \mathrm{d}, 12.0,4.8 \mathrm{~Hz})]$ signals; one olefin proton $\left[\delta_{\mathrm{H}} 5.24(\mathrm{~s})\right]$, and an anoremic proton $\left[\delta_{\mathrm{H}} 4.20(\mathrm{~d}\right.$, $J=7.6 \mathrm{~Hz}$ )] signals. The ${ }^{13} \mathrm{C}$ NMR spectrum of 1 displayed 26 carbon resonances, according to three methyl, nine methylene, four methine, four quaternary carbons, and a glucopyranosyl moiety. The NMR characters of 1 were similar to those of ent-2 $\alpha, 15,16,19$-tetrahydroxypimar-8(14)-en-19-O- $\beta$ glucopyranoside[11] except for the side chain in position C-13. The HMBC cross-peaks (Figure 2) from $\delta_{\mathrm{H}} 0.94(\mathrm{H}-17)$ to $\mathrm{C}-12, \mathrm{C}-13, \mathrm{C}-14$ and $\mathrm{C}-15$ together with the COSY correlations of $\mathrm{H}-15 / \mathrm{H}-16$ indicated the carbon signal $\delta_{\mathrm{C}} 44.5$ (t) should be connect to C-13. In addition, the HMBC cross-peaks from the anoremic proton $\delta_{\mathrm{H}} 4.20$ to $\mathrm{C}-19$, and the coupling constant $(J=7.6 \mathrm{~Hz})$ indicated that sugar moiety was attached to $\mathrm{C}-19$ via a $\beta$-linkage. Furthermore, the key expected correlations were observed as follows: from $\delta_{\mathrm{H}} 0.85(20-\mathrm{Me})$ to $\mathrm{C}-1, \mathrm{C}-5, \mathrm{C}-9$ and C-10, from $\delta_{\mathrm{H}} 1.09(18-\mathrm{Me})$ to C-3, C4, C-5 and C-19 in the HMBC spectrum, and of $\mathrm{H}-1 / \mathrm{H}-2 / \mathrm{H}-3, \mathrm{H}-5 / \mathrm{H}-6 / \mathrm{H}-7, \mathrm{H}-9 / \mathrm{H}-11 / \mathrm{H}-12$ in the ${ }^{1} \mathrm{H}-{ }^{1} \mathrm{H}$ COSY spectrum. Based on the above evidences, the planar structure of $\mathbf{1}$ was established.

The relative configuration of of $\mathbf{1}$ was established by a ROESY experiment (Figure 3). The correlations $\mathrm{H}-2 \leftrightarrow \mathrm{Me}-20$ indicated $\beta$-orientation of $2-\mathrm{OH}$, and $\mathrm{H}-19 \leftrightarrow \mathrm{Me}-20$ revealed Me-18 adopted $\beta$-orientation. Therefore, the structure of compound 1 was identified as ent-15-methylene$2 \alpha, 16,19$-trihydroxy-pimar-8(14)-ene-19-O- $\beta$-D-glucopyranoside, and named pubeside $\mathrm{F}$.

From the NMR and MS data and corresponding with those form literatures, the known entpimarame diterpenoids from the plant were identified as ent-2 $\alpha, 15 \mathrm{R}, 16,19$ - tetrahydroxypimar- $8(14)$ ene (2)[12], kirenol (3)[13], ent-2-oxo-15,16,19-trihydroxypimar-8(14)-ene (4)[8], pubeside D (5)[8], ent-2 $\alpha, 15,16$-trihydroxypimar-8(14)-en-19-oic acid (6)[8], ent-16-O-acetoxy-2 $\alpha, 16,19$ trihydroxypimar-8 (14)-ene (7) [14], ent-15-O-acetoxy-2 $\alpha, 16$, 19-trihydroxypimar-8(14)-ene (8)[14] and darutoside (9)[15].

Table 1. ${ }^{1} \mathrm{H}$ and ${ }^{13} \mathrm{C}$ NMR data for compound 1

\begin{tabular}{lllrll}
\hline Position & \multicolumn{1}{c}{$\delta_{\mathrm{C}}$} & \multicolumn{1}{c}{$\delta_{\mathrm{H}}$} & Position & \multicolumn{1}{c}{$\delta_{\mathrm{C}}$} & \multicolumn{1}{c}{$\delta_{\mathrm{H}}$} \\
\hline 1 & $50.0(\mathrm{t})$ & $1.99,1.04(1 \mathrm{H}$ each, m) & 14 & $132.6(\mathrm{~d})$ & $5.24(1 \mathrm{H}, \mathrm{s})$ \\
2 & $65.5(\mathrm{~d})$ & $3.85(1 \mathrm{H}, \mathrm{m})$ & 15 & $44.5(\mathrm{t})$ & $1.64,1.55(1 \mathrm{H} \mathrm{each,} \mathrm{m})$ \\
3 & $45.6(\mathrm{t})$ & $2.35,0.86(1 \mathrm{Heach}, \mathrm{m})$ & 16 & $60.0(\mathrm{t})$ & $3.61(2 \mathrm{H}, \mathrm{m})$ \\
4 & $40.8(\mathrm{~s})$ & & 17 & $29.1(\mathrm{q})$ & $0.94(3 \mathrm{H}, \mathrm{s})$ \\
5 & $56.7(\mathrm{~d})$ & $1.18(1 \mathrm{H}, \mathrm{m})$ & 18 & $28.5(\mathrm{q})$ & $1.09(3 \mathrm{H}, \mathrm{s})$ \\
6 & $23.5(\mathrm{t})$ & $1.73,1.31(1 \mathrm{Heach}, \mathrm{m})$ & 19 & $74.2(\mathrm{t})$ & $4.04,3.31(1 \mathrm{H}$ each, d, 11.6) \\
7 & $37.4(\mathrm{t})$ & $2.26,2.04(1 \mathrm{H}$ each, m) & 20 & $17.6(\mathrm{q})$ & $0.85(3 \mathrm{H}, \mathrm{s})$ \\
8 & $137.3(\mathrm{~s})$ & & $1^{\prime}$ & $105.1(\mathrm{~d})$ & $4.20(1 \mathrm{H}, \mathrm{d}, 7.6)$ \\
9 & $52.6(\mathrm{~d})$ & $1.81(1 \mathrm{H}, \mathrm{m})$ & $2^{\prime}$ & $75.4(\mathrm{~d})$ & $3.19(1 \mathrm{H}, \mathrm{t}, 8.4)$ \\
10 & $41.0(\mathrm{~s})$ & & $3^{\prime}$ & $78.4(\mathrm{~d})$ & $3.35(1 \mathrm{H}, \mathrm{m})$ \\
11 & $20.4(\mathrm{t})$ & $1.62(2 \mathrm{H}, \mathrm{m})$ & $4^{\prime}$ & $71.8(\mathrm{~d})$ & $3.28(1 \mathrm{H}, \mathrm{m})$ \\
12 & $36.5(\mathrm{t})$ & $1.58,1.17(1 \mathrm{H}$ each, m) & $5^{\prime}$ & $77.9(\mathrm{~d})$ & $3.27(1 \mathrm{H}, \mathrm{m})$ \\
13 & $34.0(\mathrm{~s})$ & & $6^{\prime}$ & $61.8(\mathrm{t})$ & $3.87(1 \mathrm{H}, \mathrm{dd}, 12.0,6.2)$ \\
& & & & $3.71(1 \mathrm{H}, \mathrm{dd}, 12.0,4.8)$ \\
\hline
\end{tabular}

*400 MHz for ${ }^{1} \mathrm{H}$ NMR and $100 \mathrm{MHz}$ for ${ }^{13} \mathrm{C}$ NMR in MeOD in ppm, $J$ in $\mathrm{Hz}$

\section{Acknowledgments}

This research was financially supported by Anhui Province College Excellent Young Talents Fund (2013SQRL041ZD), postdoctoral Start-up Fund of Anhui University (j01002021), and postdoctoral fund of Anhui Province (2016B129). We also thank the analytical group of the State Key Laboratory of Phytochemistry and Plant Resources in West China, Kunming Institute of Botany, Chinese Academy of Sciences for all spectra tests.

\section{Supporting Information}

Supporting information accompanies this paper on http://www.acgpubs.org/RNP 


\section{ORCID}

Fengqing Xu: 0000-0001-5956-1556

Huaping Hu: 0000-0001-6035-9574

Ying Li: 0000-0002-3582-0573

Yashuo Ren: 0000-0002-3031-8103

Hongsu Zhao: 0000-0001-9269-7893

Qi Huang: 0000-0002-4252-9557

Jutao Wang: $\underline{0000-0001-8258-7658}$

\section{References}

[1] Flora of China Editorial Committee (1979). Flora Reipublicae Popularis Sinicae. Beijing: Science Press. Vol. 75, 339-340.

[2] Chinese Pharmacopoeia (2015). Chinese Pharmacopoeia Commission. Beijing: Chinese Medical Science and Technology Press. Vol. I, 368.

[3] J. P. Wang, H. X. Xu, Y. X. Wu, Y. J.Ye, J. L. Ruan, C. M. Xiong, and Y. L. Cai (2011). Ent-16 beta,17dihydroxy-kauran-19-oic acid, a kaurane diterpene acid from Siegesbeckia pubescens, presents antiplatelet and antithrombotic effects in rats, Phytomedicine 18, 873-878

[4] Z. M. Wang, S. G. Zhu, Z. W. Wu, Y. Lu, H. Z. Fu and R. Q. Qian (2011). Kirenol upregulates nuclear Annexin-1 which interacts with NF-kappa B to attenuate synovial inflammation of collagen-induced arthritis in rats, J. Ethnopharmacol. 137, 774-782.

[5] J. Xiao, R. B. Yang, L. Yang, X. H. Fan, W. W. Liu and W. B. Deng (2015). Kirenol attenuates experimental autoimmune Encephalomyelitis by Inhibiting Differentiation of Th1 and Th17 Cells and Inducing Apoptosis of Effector T Cells, Sci. Rep. 5, 1-8.

[6] H. M. Kim, C. Y. Kim, M. H. Kwon, T. Y. Shin and E. J. Lee (1997). Suppression of anaphylactic reaction in murine by Siegesbeckia pubescens, Arch. Pharmacol. Res. 20, 122-127.

[7] G. X. Chou, R. M. Jin, Z. T. Wang and C. X. Chen (2005). Study on antithrombotic fraction of herb Siegesbeckia, Acta Univ Tradit Med Sin Pharmacol Shanghai. 19, 39-41.

[8] R.Wang, W. H. Chen and Y. P. Shi (2010). Ent-kaurane and ent-pimarane diterpenoids from Siegesbeckia pubescens, J. Nat. Prod. 73, 17-21.

[9] C. Wang, F. Q. Xu, J. H. Shang, H. Xiao, W. W. Fan, F. W. Dong, J. M. Hu and J. Zhou (2013). Cycloartane triterpenoid saponins from water soluble of Passiflora edulis Sims and their antidepressantlike effects, J. Ethnopharmacol. 148, 812-817.

[10] L. L. Pan, P. L. Fang, X. J. Zhang, W. Ni, L. Li, L. M. Yang, C. X. Chen, Y. T. Zhang, C. T. Li, X. J. Hao and H. Y. Liu (2011). Tigliane-type diterpenoid glycosides from Euphorbia fifcheriana, J. Nat. Prod. 74, 1508-1512.

[11] Y. Xiang, H. Zhang, C. Q. Fan and J. M. Yue (2004). Novel diterpenoids and diterpenoid glycosides from Siegesbeckia orientalis, J. Nat. Prod. 67, 1517-1521.

[12] J. B. Wang, H. Q. Duan, Y. Wang, B. Pan, C. Gao, C. Y. Gai, Q. Wu and H. Z. Fu (2017). Ent-Strobane and ent-pimarane diterpenoids from Siegesbeckia Pubescens, J. Nat. Prod. 80, 19-29.

[13] K. Liu and E. Ro“der (1991). Diterpene aus Siegesbeckia glabrescens, Planta Med. 57, 395-396.

[14] J. Xiong, Y. B. Ma and Y. L. Xu (1997). The constituents of Siegesbeckia orientalis, Nat. Prod. Sci. 3, 14-18.

[15] J. H. Kim, K. D. Han, K. Yamasaki and O. Tanaka (1979). Darutoside, a diterpenoid from Siegesbecia pubescens and its structure revision, Phytochemistry 18, 894-895.

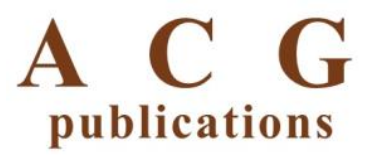

(C) 2018 ACG Publications 